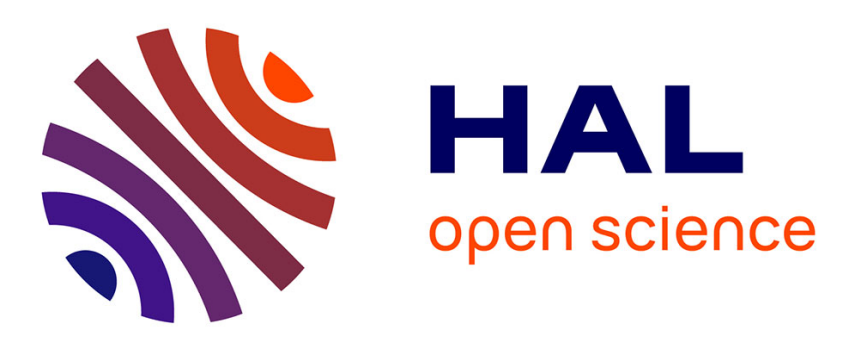

\title{
Chemical oxygen iodine laser : technical overview and future potential

\author{
W. Bohn
}

\section{To cite this version:}

W. Bohn. Chemical oxygen iodine laser : technical overview and future potential. Journal de Physique

IV Proceedings, 1994, 04 (C4), pp.C4-772-C4-772. 10.1051/jp4:19944212 . jpa-00252679

\section{HAL Id: jpa-00252679 https://hal.science/jpa-00252679}

Submitted on 1 Jan 1994

HAL is a multi-disciplinary open access archive for the deposit and dissemination of scientific research documents, whether they are published or not. The documents may come from teaching and research institutions in France or abroad, or from public or private research centers.
L'archive ouverte pluridisciplinaire HAL, est destinée au dépôt et à la diffusion de documents scientifiques de niveau recherche, publiés ou non, émanant des établissements d'enseignement et de recherche français ou étrangers, des laboratoires publics ou privés. 


\title{
Chemical oxygen iodine laser: technical overview and future potential
}

\author{
W.L. BOHN
}

DLR Institute for Technical Physics, Stuttgart, Germany

As the only true electronic transition chemical laser the Oxygen Iodine Chemical Laser (COIL) has found great attention in the international R\&D community with respect to high brightness applications. A brief outline of the history of COIL development will be given while introducing the major processes that characterize the physico-chemical properties of the laser. In particular, the crucial importance of the generation of $\mathrm{O}_{2}\left({ }^{1} \Delta\right)$ molecules on the overall performance will be demonstrated and the current understanding of the basic processes in the liquid phase of BHP (basic hydrogen peroxide) will be reviewed.

Special attention will be given to advanced generator concepts recently introduced by Russian work.

Limitations due to excited Oxygen quenching and open questions related to Iodine mixing and dissociation will be addressed in a comprehensive discussion of the laser power optimization.

Pulsed operation of otherwise CW COIL has implications for high power short wavelength generation. This aspect will be included in a preliminary evaluation of the future application potential of COIL. 